Covered in: ERIH PLUS, CEEOL, Index Copernicus, CrossRef, CrossCheck, J-Gate, Google Scholar, Ideas RePeC, Econpapers, Socionet, KVK, WorldCat.

2020, Volume 9, Issue 1, pages: 101-111 | doi: 10.18662/lumenss/9.1/36

\section{Environmental Manager and its Importance in the Development of the Company}

\section{Ana Georgiana \\ CĂLUGĂRESCU ${ }^{1}$}

${ }^{1}$ Valahia University of Targoviste, Romania, $m$ ana g@yahoo.com
Abstract: As a result of natural and artificial changes, it is the environment that suffers. The environment is an integral part of the development of society by directly linking natural resources to people. Any area can have tourist potential. The more properly exploited the resources owned by the environment, invested in areas of interest and promoted, the more people in those areas will have to gain. At the same time, the environmental education that the students can learn in the middle of nature, testing the own person the benefits offered by the environment and the consequences that can derive from people's reckless actions can bring significant changes on their personalities and can form responsible people who protect the environment, who live and want to stop the harmful phenomena. Building a bridge between education and the environment, strengthening the connections between people and nature influences both physical and mental health. Awareness of climate change in recent times and the desire to stop these phenomena can save communities from natural disasters, produced more and more often.

Keywords: development; environment; management; change.

How to cite: Călugărescu, A.G. (2020). Environmental Manager and its Importance in the Development of the Company. Logos Universality Mentality Education Novelty: Social Sciences, 9(1), 101-111. doi: 10.18662/lumenss/9.1/36 


\section{Introduction}

The current society is in full development, change, evolution. Regardless of the activity, we carry out, we are surrounded by people. The changes that must be imposed on the environment will be based on the sustainable development of the respective company. The changes need to be done so that the impact on people is analyzed first and a balance is struck between the positive and the negative points, of which those with the most pronounced impact are those that give a plus to the people in the respective communities.

The biggest influence on the sustainable development of the company is the environmental manager. The manager plays the main role in sizing the performances of the unit managed, be it, country, an enterprise of any kind, educational institution or culture (Puiu, 2007, p. 36). Thus, he is the one who designs activities and properly forecasts the future effects of the present actions. It is not important to plan an action plan on paper, to carry out all the duties of the position and to remain at this level, it is important to act, to implement the outlined plans or even to exceed these forecasts.

The manager is the key to the development of any company. Analogous to the environment can have positive effects if changes are made with and for people. Increasingly, there is talk of stopping the phenomenon of pollution, of involving as many people in ecological activities and stopping deforestation. A society can develop sustainably if the resources are used both for the present and especially for the future. There can be no talk of an increase in the standard of living if deforestation is carried out with the highest percentage, without any trees being planted afterward, we cannot say that we evolve as long as we, as a people, forget the values and ancestral attitudes, we degrade the environment, we build without permits, and we use natural resources only for present gains. The manager is the right man at the right place or is the person who best corresponds to the Romanian proverb the man sanctifies the place. A manager is a person who can see in the future and can see the results of his decisions. He is a man who sets aside personality problems and can make decisions based on facts (Belker, 2002, p.12).

Therefore, the manager must think for an entire group or a community, for the profit obtained by all the people involved, not just for his own person. A good leader is the one who first thinks about the good of 
others and after the person himself, he is the one who can lead the community beautifully towards the light.

\section{Manager - skills, skills}

Any manager must possess the skills and abilities that are required for the management act. Both conceptual, human and technical skills are meant to help the person involved in decision making. The manager must see the organization as a whole, think strategically and make long-term decisions, must be able to work with and for people, understand the tasks offered, the methods, techniques or even the equipment involved (Zlate, 2004, p.171). Zlate M. (2007, pp. 217-218) classifies the managers according to these abilities, as follows: top managers - who possess conceptual skills and subordinate the other hierarchical levels, middle manager - having human skills with subordinate executives or managers and front line managers - working directly with executors and having technical skills.

In any classification there is a manager, it is certain that he has a complex profession that imposes the efficiency of the respective person in the maximum number of activities. It is not enough for a manager to have specific skills for a particular area of work, it is necessary for the person to be able to fold in any field and know every detail of the directions in which they act. The modern manager involves a large number of skills and orientations, many of which involve skills related to statistics, the use of information technology, accounting, and mathematics. Management emphasizes rational problem solving and logical thinking. As management necessarily involves people, it is of great importance to possess interpersonal skills - the ability to work with individuals but also with work teams (Cornescu, 2003, p. 9). For each important leader, it is not the field that he is specialized in but the mix of specializations he can obtain, important is the knowledge bag from different fields with which he is endowed. To begin with, he must specialize, test how he works and only then applies for such a position.

In particular, the environmental manager must present extensive research both in the respective field and on the other levels. These roles, duties, and authority shaped to ensure the requirements of an environmental management system, requirements that are established at the national level, implemented at the regional level and maintained according to the system. These performances should be reported to senior management as a basis for improving the environmental management system. Personnel performing tasks that can cause significant environmental impact must be competent on 
the basis of appropriate education and training and / or experience. It is essential for employees at each relevant function and level to be aware of the importance and compliance with environmental policy, the significant environmental impact, their roles and responsibilities in achieving compliance with environmental policy and procedures, the possible consequences of deviation from environmental procedure (Neagu, 2015). The emphasis on each manager falls on his personality. Each person differs and implicitly the way of thinking, action, and the decision depends so much on the training of the respective person but especially on their own personality. There are very well trained people who know the theoretical notions completely and are constantly improving but when they are faced with a new challenge or a major hesitant decision, they cannot decide on their own or worse abandon it.

The personality of any person develops over time, influenced by environmental, social, cultural and educational factors with which man interacts throughout his life. At the same time, the managerial personality is not an inherent asset but is shaped in time. Thus, managerial psychology studies the manager's personality from the perspective of performing his functions: forecasting, decision, organization, command, coordination, and control (Boghaty, 2007).

In order for the decisions taken by a leader to be correct all these functions must be intertwined, the managerial act cannot be completed without one another. If the forecast is made correctly on paper but not applied properly or the control over its decisions is missing, there is a high probability that the managerial act will fail.

Avram E. argues that a manager performs managerial functions quietly and with minimal tension and conflict (Avram, Cooper, 2008). So, it is important for the manager to outline the action plans but to implement them properly, without additional energy consumption by himself or other persons involved.

So the driving style differs depending on the person involved. The leadership style is the proper way of being, behaving and acting of the manager in the management process. The concept of leadership style brings together in a dynamic ensemble the psychic and psychosocial characteristics and particularities, the qualities, the knowledge and the behaviors of the leaders in the exercise of the appropriate management (Petrovici, 2001, p. 133).

The leadership style reflects the use of knowledge, qualities, and aptitudes in the relationships with subordinates and the effective development of these work processes (Verboncu, 2005, p.25). 
Regardless of the position he holds, the level of living he has, the knowledge he has, a good manager works through people for people. It is the one who decides for a whole group, whether it is bigger or smaller, or whether it consists of close persons or simple knowledge. The decisions that need to be made are fair, qualitative and can support most of the organization. There are no correct decisions if they have positive effects in the short term or only for a very small percentage of the people directly or indirectly involved. Although we live in the era of modern civilization, technological development and personal development, more and more people at the head of institutions want to decide in their favor first and then for the other people.

These conceptions must disappear, regress and be part of truly new development not only in acts. The visible achievements are what make the difference between a good leader and an indifferent one, the standard of living of the people in the community tells us if the society is in progress, although this progress is often only on paper, there are still many people that have been so professionally involved, but above all, he has decided to change the lives of those around him.

The coherence of the managerial act is given by ensuring the observance of all the duties. The environmental manager must identify the development needs and, following the analyses carried out, formulate programs and projects with specific objectives related to the changes pursued through selected investment priorities.

Jose Manuel Barroso argues that our success depends on the real involvement of Europe's leaders and institutions. Our new agenda requires a coordinated response at the European level, involving social partners and civil society. Only together we can counteract the effects of the crisis and we can get out of this situation stronger. We have new tools and a new ambition at our disposal. All we have to do is take action (CJ Buzau, 2016).

\section{The natural and ancient potential in the northern area of Buzău County}

For sustainable development of the county a strategy of research and innovation must be implemented, of efficient use of the resources so as to offer favorable conditions for the search for new jobs. At the same time, investments in education contribute to improving professional prospects and reducing poverty. For quality education, it is necessary for every student to know the environment of origin, its culture, its natural benefits, and its importance. Climate change does not occur by itself but must be diminished 
by humans. For these reasons, I consider it essential for the society to involve students in actions to save the environment, to know it, to interact directly. The hydrographic basin of Slănic de Buzău, through the complexity of the elements of the natural setting (carved structure, the presence of diaper carvings, of special natural phenomena, of biogeographic elements of Mediterranean type), through the numerous archaeological pieces of evidence that highlight the popularity of this ancient times. regions Neolithic settlements in the Săpoca and Aldeni area, elements corresponding to the Bronze Age, tools made of metal corresponding to the metal age), through the diversity of ethno-folkloric and cultural elements (handicrafts, woodworking, customs and traditions characteristic of the area). a region with an important educational potential.

The beauty of these lands and the tumultuous historical past have attracted attention and have been an inspiration for many skiers and artists. Alexandru Vlahuţă describes the bisocene hills in the work "picturesque Romania", Odobescu in "Pseudokinegetikos", Grigorescu painted here "Călăra" and "Călăra" Țăranca de Bisoca "and Ștefan Popescu" Nature viewers ". Also worth mentioning is the incident from the Găvanu chapel, which took place around 1821, in which a group of boyars and merchants were killed by the Turks, which is at the base of the novel "Catastrophe happened in Găvanul Mountain" by Alexandru Pelimon.

Also in these areas, students can discover many forms of relief, unique in the country some of these, among which are: the mountain massifs Siriu, Cicaş, Bucegi, Penteleu, forms of the structural relief represented by the alignment of hogbakuri, small, suspended slopes (Ivănețu, Monteoru peaks), the live fires from Terca that represent a unique natural phenomenon in the country, the rocks from the Red River spectacular cliffs from the red, hard rocks, formed by reddish mentality due to the iron oxides, the waves of stone. at Lopătari - dating back over 16 million years and seems to be the proof of the framing of these areas in the Tethys Sea.

The characteristic relief forms developed on the salt are imposed in the north of the sub-Carpathians on Miocene deposits. On the salt have resulted in complex forms - linear and tubular pits, uval dolines, oats, caves, underground drainage galleries of more than $10 \mathrm{~m}$. the second in the world. The second important cave is the cave with three entrances, which occupies the fourth place in length. The erosion control from the white bush from the confluence of the Jgheabului with the Slănicul, called Grunj, represents the result of the surface modeling agents. Another monument of nature is the stone block "Masa Lui Bucur", located in the hills of Bisocii and 
represents a stone block with a pseudoplanar surface, weighing approximately $150 \mathrm{t}$, placed on three other small stones, creating an image of a Dacian stone. with three legs. Also in these areas can be discovered by students and the fossil area from Vintilă Voda - Beșlii where we meet a lot of places with shells and snails preserved in stone. They are marine animals between 1 and 12 million years old from ancient Parathetys.

Another point of interest for the people who are keen on learning by discovering the pupils is the lakes in the respective areas. These are formed by tracing some marno - greasy formations, formed in dolines developed on limestone sandstone having an advanced degree of coloration, developed on saliferous Miocene deposits, accumulation lakes or even mineral springs. These aspects are complemented by the natural landscapes represented by the different types of forests, through which the student can accumulate the basic information in knowing the vegetation in the area of Romania. Although the present society has modern accents, in these areas there are numerous houses that have kept their tradition, buildings of hundreds of years still talking about our pasts. Along with the history, the student can also learn the traditional crafts, those that reflect the concern and the craftsmanship of the inhabitants to model and transform different materials and raw materials into products necessary for the development of the household activities, among which we can list: pottery, weaving, woodworking, woodworking. The nature of the area makes the educational activities, in fact, a desire, both from the qualified person to program this type of education but also for the student who comes in contact with it. We cannot bring improvements to the education system just by simply changing the order of the chapters, introducing new notions that the student must learn or demand more and more from each one. The change must be radical and I consider it necessary for every student to be able to get in touch with nature, with everything around us, with real life. It is important for the student to feel useful, to know that he has discovered characteristics or that he has made an object. Learning in kind has benefits not only on the education system but also on the students' psychic system.

\section{Analysis of the population of Buzau County}

At the same time, the environmental manager must analyze in-depth the psychological profiles of the people in the action area. Thus, he will also act favorably on their meaning. Each region of the country is different, each person has their own way of perceiving the environment. 
In the intercultural psychology it is well known that, when you develop the psychological profile of a population, you make certain statistical generalizations that capture only the general, typological and nomothetic tendencies, not all the idiographic aspects of each member of the respective population (David, 2015, p. 21).

Thus for a detailed analysis, not only statistical data but direct interactions with people are sufficient. By observing them we can describe the profile of a locality, the needs and the options that the people of the respective community have.

If we analyze the statistical data at the county level, we will see small fluctuations in the number of employees in 2019. For a community's progress and its sustainable development, it is necessary that the production increase and the number of people involved are significantly higher... If at present a significant percentage of the employees are directed to industry and services, I think it is necessary that the involvement in agriculture and related services can make this community significant progress.

Mud is a reality. As long as we step into it and get dirty, it's a reality. But also from the mud is born the lily, also from the mud comes the life and the lotus flower. We are captivated that we no longer see the diamond that hides it (Pleşoianu, 2019, p. 12). Just as the young people in the present day flee the "bottom" job to live with unemployment benefits, more and more young people get laid off without a job. The unemployment rate at the end of October 2019 was $6.7 \%$.

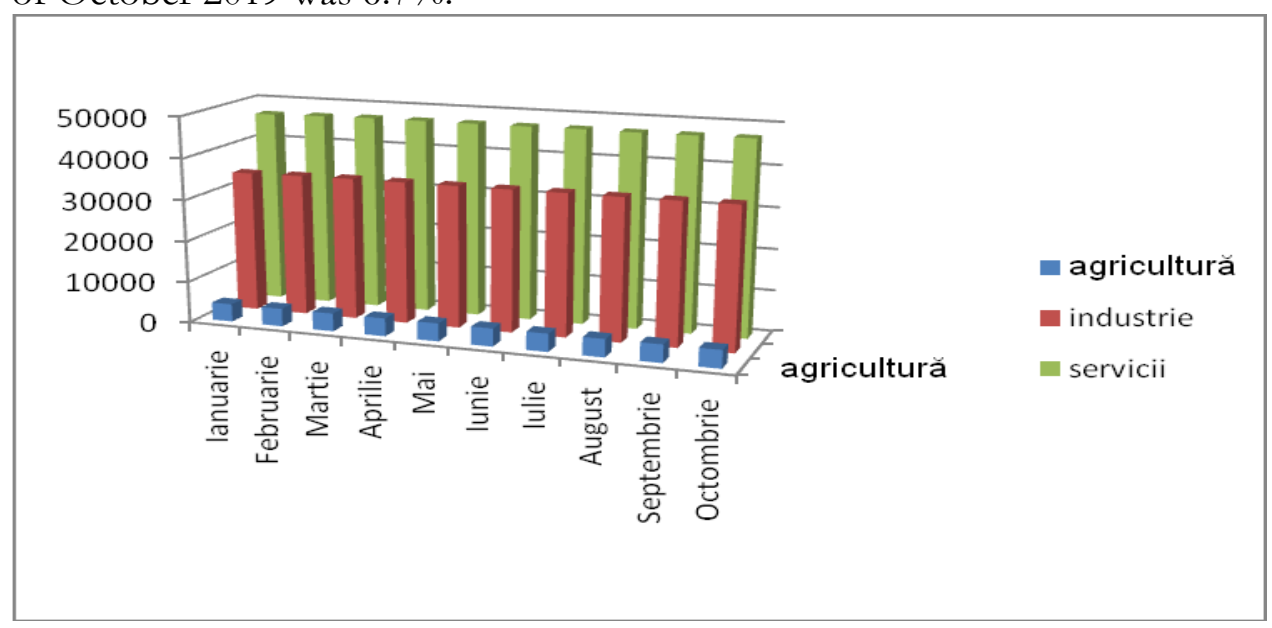

Fig. 1. The number of employees

Source: NIS Buzău County Statistics Department (2020) 


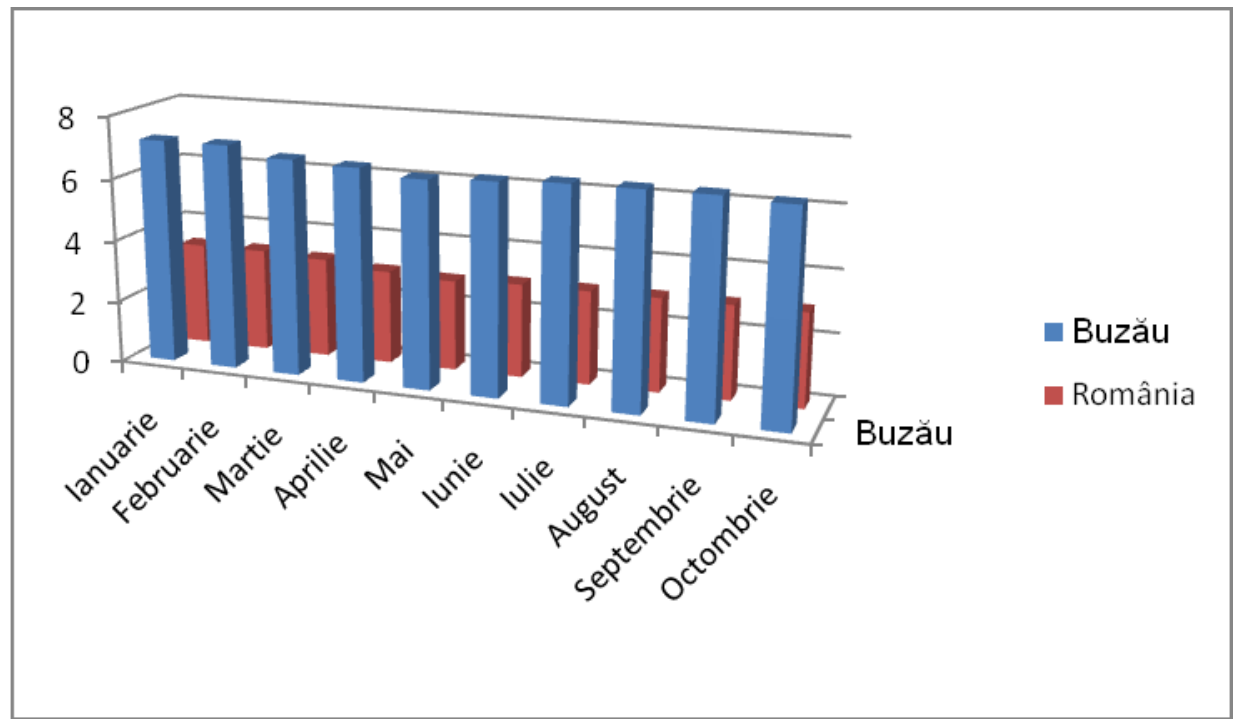

Fig. 2. Unemployment rate

Source: INS Buzău County

Statistics Department, As can be seen, the percentage of unemployment in Buzau county is double compared to the one registered in the country. This percentage can be reduced if local authorities and educational institutions act according to a common plan for the young generation. Some young people, even adults, but sometimes even unselected students may not be able to use operational thinking - formally in/in all areas, at times when they have gained experience or have a particular interest in seeking the truth (Crahay, 2009). Thus, realizing that many young people can develop skills only in certain fields and setting up and then offering the positions they are specialized in can represent an essential element in the sustainable development of society. The progressive increase of the speed of cognitive processing makes possible the interdisciplinary approaches, the manifestation of the combinations of abstract information (Neacșu, 2019, p. 91). This cognitive development starts in educational institutions. In order to integrate young people into work, the schooling units had to analyze the labor market and its requirements and, after proposing programs designed for these needs.

\section{Conclusions}

Although Romania, has a wide range of natural resources, both surface and underground, there is a large deficit of their exploitation. As can 
be seen in the description above, Buzau County can be an important tourist point, with the possibility of attracting tourists both during summer and during winter. The beautiful landscapes, some of them unique in the country or even at the European level, the natural springs, the preservation of traditions, customs, customs in certain areas can be of interest both from the inhabitants of the country and from outside it.

The launch of several accommodation centers, especially for school camps, through which we can educate students in civic spirit, can be essential for the economic development of the regions. Ecological education is the one that can stop the pollution of the environment. Although in schools there are various activities where students are presented with pictures, pictures, films for it, there are still many people who bring serious scars to the environment, considering that at one point it regenerates. The problem is that all these students are our future and our non-involvement in their education will have visible effects in the future.

Therefore, in order to make progress in the labor market, the student from the earliest age must be modeled. Usually, it internalizes external requirements, values, and models, realizing the importance of the educational activity. Finally developing sentimental debt, responsibilities in relation to learning tasks, professional aspirations including the desire to be useful to society.

The managerial act implies a special responsibility and in particular, environmental management represents the source of the company. We cannot change the mindsets of a community but we can change the way of life of the people in the respective settlements. In order to develop an action plan, all data with direct or indirect implications on people must be analyzed.

Targeting young people to various trades and development actions, highlighting the resources available to their regions of origin, using these resources responsibly, developing agriculture and related activities, exploiting agricultural land and leaving it can bring significant growth to the economy.

\section{Acknowledgement}

This paper was co-financed from the Human Capital Operational Program 2014-2020, project number POCU / 380/6/13/125245 no. 36482 / 23.05.2019 "Excellence in interdisciplinary $\mathrm{PhD}$ and post- $\mathrm{PhD}$ research, career alternatives through entrepreneurial initiative (EXCIA)", coordinator The Bucharest University of Economic Studies". 


\section{References}

Avram, E., \& Cooper, C. (2008). Organizational - managerial psychology - Current trends. Polirom.

Belker, B. L. (2002). I am manager. Teora.

Boghaty, Z. (2007). Handbook of techniques and methods in labor and organizational psychology. Polirom.

CJ Buzau. (2016). Buzău County Sustainable Development Strategy and Action Plan 2014 - 2020. http://cjbuzau.ro/wpcontent/uploads/2017/07/Strategia-2014-2020-modified11.2016.pdf

Cornescu, V. (2003). Management from theory to practice. University of Bucharest Publishing House.

Crahay, M. (2009). The psychology of education. Trei.

David, D. (2015). Psychology of the Romanian People. Polirom.

National Institute of Statistics (NIS), Buzău County Statistics Department. (2020). Rapoarte statistice. www.buzau.insse.ro/desprenoi/rapoarte-statistice/

Neacşu, I. (2019). Neurodidactics of Learning and Cognitive Psychology. Polirom.

Neagu, C. (2015). The stages of implementing an environmental management system in an organization. www.revistadestatistica.ro/suplement/wpcontent/uploads/2015/10/RRSS 102015 A07RO.pdf

Petrovici, V. (2001). Leadership styles and management efficiency. Economic.

Pleşoianu, L. (2019). Romania, Country of a possible dream. Prestige.

Puiu, A. (2007). Management. Analyzes and comparative studies. Economic Independence.

Verboncu, I. (2005). Do we want to drive? Economic.

Zlate, M. (2004). Leadership, and management, Polirom.

Zlate, M. (2007). Treaty of organizational-managerial psychology (2 ${ }^{\text {nd }}$ vol.). Polirom. 